\title{
Self-assessment in Oral English Teaching
}

\author{
Song Lihui \\ School of Foreign Languages, Qilu University of Technology \\ Daxue Road, Western University Science Park, Jinan, Shandong Province, China
}

\begin{abstract}
With the development of the new curriculum reform in recent years, college English teachers have given more and more attention to the development of students' oral communication competence, but how to evaluate students' oral English competence has always been a headache for teachers. Based on the status quo of the college oral English teaching, the author suggests that self-assessment should be introduced into the teaching process for the student to assess their learning process and results in order to improve their language using ability, thus to promote the college oral English teaching reform.
\end{abstract}

Key Words: self-assessment; learner autonomy; oral English

\section{Introduction}

In 1970s, the term "autonomy" was introduced by Henri Holec to the field of second language pedagogy. Since then autonomous learning has been discussed to find out whether it can help students to improve their learning. Since the emphasis has switched from teachers' management to students' self-direction, it might be a good way for students to promote learning.

Traditionally, the task of assessing students' learning achievements mainly goes to the teachers. Many scholars assume that assessment plays a crucial role of feedback in learning and research has clearly shown that feedback promotes learning and achievement [1]. But due to some reasons, many students seldom get informative feedback on their work from teachers [2].

In the year of 1980, Oscarson put forward the notion of self-assessment, which he thought could help students set goals, try to achieve the goals and was an important skill for effective learning. Bailey defined self-assessment as "procedures by which the learners themselves evaluate their language skills and knowledge" [3]. Orsmond \& Merry is prepared to acknowledge that in first language assessment, self-assessment is effective because it can help students to develop a better understanding of the purpose of the assignment and the assessment criteria [4]. Some research on language pedagogy also recommends that teachers should provide opportunities for students to assess their language level so as to help them focus on their own learning [5]. Later the method of self-assessment has gained more and more attention, but most scholars and teachers focus on the self-assessment ability in reading and writing while ignoring how to improve oral English competence through self-assessment.

\section{Status Quo of Oral English Assessment}

China's college English teaching has made gratifying achievements in the past decades and the students have greatly improved their English level. However, their comprehensive ability of using English is still unsatisfactory. In order to change the current situation and meet the needs of the social development, the English teachers must strengthen practical English teaching, especially the oral English practice. Thus taking feasible measures to improve college students' 
ability of information exchange becomes an urgent task.

According to College English Curriculum Requirements, "The objective of College English is to develop students' ability to use English in a well-rounded way, especially in listening and speaking, so that in their future studies and careers as well as social interactions they will be able to communicate effectively, and at the same time enhance their ability to study independently and improve their general cultural awareness so as to meet the needs of China's social development and international exchanges."[6] However, the oral English teaching is the most difficult and the weakest in the teaching process. If we want to improve the oral English competence, it would be essential to reform the current teaching method.

Summative assessment has once been widely used to assess the students' English learning attainment, which mainly relies on the teachers' scores. However, in the aspect of oral English, there is even almost no required standard to judge students' communication ability. The method of exam-oriented education greatly influenced the English teaching. Students only need to write something instead of speaking something when they take part in English exams. When asked about their attitude to oral English, most of the students think there is no need for them to speak because the speaking level does not affect their total scores. On the other hand, classroom time is limited. Nowadays, in many universities, students will have four English classes per week, which lasts four semesters. With limited time and great teaching content, teachers do not have enough time to train students' oral communication ability.

\section{Methods of Self-assessment in Oral English Teaching}

Oscarson puts forward that there are four main benefits of self-assessment: firstly, self-assessment trains learners to evaluate the effectiveness of their communication which is beneficial to learning itself; secondly, it trains learners' awareness of the learning process and stimulate them to consider course content and assessment critically; thirdly, it enhances their knowledge of the variety of possible goals in language learning, which leaves them in a better position to exercise control over their own learning and to influence the direction of classroom activities; fourthly, it expands the range of assessment criteria to include areas in which learners have special competence, such as the evaluation of their own needs and affective dimensions of the learning process [7]. Since self-assessment is beneficial to the learners, teachers can practice it in the oral English teaching process. College English teachers can ask students to do as follows:

\subsection{Abandoning the traditional learning concept and mode}

Whether the learning concept is correct or not is the key to success of English teaching reform. Although College English Curriculum Requirements suggests strengthening the cultivation of listening and speaking ability, still quite a few students focus on cultivating the reading ability and keen to learn vocabulary and grammar instead of practical oral English. Thus, the traditional learning concept and learning mode has become a great obstacle in the development of college students' oral English competence.

\subsection{Self-assessment implementation}

English teachers should strive to transform the classroom from a place of teachers' instruction into a place of communication. Teachers can provide more activities. For example, firstly, English teachers ask students to set goals in oral English, which guides students to become active learners. The goal set by the 
learners themselves would have certain effect on their autonomous learning, which can promote their autonomous learning motivation and make them see certain aspects of their progress. Then the students would know more clearly what to do, how to do and they can control the target to monitor their own learning process. Of course, the target should not be too low or too high. Or else, it is not conducive to the progress of the students, so the teachers should encourage the students to set specific and a little challenging learning objectives.

Secondly, teachers should guide students to do self-assessment after oral practice. Every day teachers can spare five minutes for the students to do English report before lecturing. Some additional text-related contents can also appear in their oral list with the expansion of vocabulary and related cultural knowledge. In this way, students will become interested and motivated, and the classroom atmosphere will soon perk up. After discussing for ten minutes, students can be guided into the text reading. Through this activity, the students may have more opportunities to open mouth and do brain-storming, which will lead them to participate fully in the learning process.

In classroom teaching, the students can also be encouraged to do cosplay. The current college English textbook contents are close to life and very interesting. In the activities of cosplay, the students can try different identities and feel free to express their true feelings in different scenarios. After class, teachers also can give some appropriate topics to students for group discussion. Group discussion activities can not only increase students' oral practice opportunities, but also enable students to do active thinking.

A few minutes before time is up, teachers can make the students do self-assessment. Self-assessment has been assumed to be effective for learning because it promotes learners' self-regulatory learning and autonomy
[8] [9]. This activity can help students understand their learning, which can't be compared by the traditional assessment methods. Self-assessment not only includes the assessment of knowledge, but also should contain the emotional factors, such as the learning motivation, learning interest, learning habits and learning attitude, etc. Under the guidance of teachers, students can understand their learning and some related factors in the learning process, and adjust learning strategies.

\subsection{Reflecting on the former achievements}

After certain periods, students should be asked to compare the current achievement with the past, finding out what factors contribute to the success. When students find they have made progress to some extent, they would be happy to continue self-assessment and make further progress. Students' attitudes towards self-assessment will be more and more positive as they gain more and more experience, although initially they may perceive the requirement as a great pain. At the same time, the effect of the self-assessment can be further promoted by peers' and teachers' feedback, which can help them reduce the negative feelings and assess the former assumptions about learning.

\section{Conclusion}

The following implications and suggestions should also be included: Firstly, the formal training of doing self-assessment is very important. Students should understand the assessment standards and criteria clearly, which will help them make suitable goals, thus internalizing into their unified criterion. Students who set goals, make flexible plans to meet them and monitor their progress tend to learn more and do better than students who do not [10]. Secondly, the feedback of the teachers and classmates are very important. In the process of self-assessment, students tend to focus on their 
own shortcomings, while ignoring their own advantages. Teachers' feedback can guide students to face their own advantages and disadvantages more comprehensively and objectively, and analyze their overall language ability.

A person's perception of his abilities may have substantial consequences for his actions [11]. The procedure of self-assessment involves students in judging their own learning achievements and process, which would help students actively assess their own learning performance. Along with the deepening of China's reform and opening up, international communication activities will increase tremendously. To improve students' oral English competence has become more and more important. The self-assessment of one's own oral English can stimulate the students' enthusiasm of learning and using English, and it will also have a backwash effect on teaching.

\section{References}

[1] Bangert-Drowns, R. L., Kulik, C. C., Kulik, J. A., \&Morgan, M. T. , The instructional effect of feedback in test-like events. Review of Educational Research, 61, pp.213-238, 1991.

[2] Black, P., \& Wiliam, D., Inside the black box:Raising standards through classroom assessment. Phi Delta Kappan, 80, pp.139-148, 1998

[3] Bailey, K. M., Learning about language assessment. Cambridge, MA:Heinle \& Heinle, 1998

[4] Orsmond, P., \& Merry, S., A study in self-assessment: Tutor and students' perceptions of performance criteria. Assessment \& Evaluation in Higher Education, 22(4), pp.357-370, 1997.

[5] Yuh-Mei Chen, Learning to self-assess oral performance in English: A longitudinal case study, Language Teaching Research 12,2 pp. 235-262, 2008.
[6] Ministry of Education of the People's Republic of China: College English Curriculum Requirements, Beijing:Tsinghua University Press, 2007.

[7] P. Benson, Teaching and Researching Autonomy in Language Learning. Harlow: Pearson Education, 2001.

[8] Dann R, Promoting assessment as learning: Improving the learning process. New York: Routledge, 2002.

[9] Oscarson M (1997). Self-assessment of foreign and second language proficiency. In C. Clapham and D. Corson (Eds), Encyclopedia of language and education, Volume 7: Language testing and assessment (pp. 175-187). Dordrecht, Netherlands: Kluwer Academic., 1997.

[10]Heidi Andrade \& Anna Valtcheva, Promoting Learning and Achievement Through Self-Assessment, Theory Into Practice, 48:12-19, 2009

[11]Silvia Dominguez-Martinez and Otto $\mathrm{H}$. Swank, A Simple Model of Self-Assessment, The Economic Journal, 119 (July), pp.1225-1241, 2009. 